\title{
BAKTERI PADA KARANG SCLERACTINIA DI KAWASAN PERAIRAN BUNAKEN, MOROTAI DAN RAJA AMPAT
}

\author{
(Bacteria on Scleractinia Corals in Bunaken, Morotai and Raja Ampat) \\ Eghbert Elvan Ampou ${ }^{1 *}$, lis Triyulianti ${ }^{1}$, Nuryani Widagti ${ }^{1}$ \\ Suciadi Catur Nugroho², dan Yuli Pancawati ${ }^{3}$ \\ ${ }^{1}$ Balai Riset dan Observasi Laut, Badan Riset Sumber Daya Manusia Kelautan dan Perikanan, \\ Kementerian Kelautan dan Perikanan, \\ Jl. Baru Perancak, Jembrana, Bali 82251 \\ 2 Loka Riset Perikanan Tuna, Badan Riset Sumber Daya Manusia Kelautan dan \\ Perikanan,Kementerian Kelautan dan Perikanan \\ JI. Mertasari No.140, Sidakarya, Kec. Denpasar Selatan, Kota Denpasar, Bali 80224 \\ 3 Balai Karantina Ikan, Pengendalian Mutu dan Keamanan Hasil Perikanan Surabaya II, \\ Kementerian Kelautan dan Perikanan \\ J. Kalimas Baru No. 86, Surabaya, Jawa Timur 60165 \\ Email: eghbert.ampou@kkp.go.id
}

\begin{abstract}
Research on hard coral (Scleractinian coral) contaminated with bacteria is still not much done, especially in Indonesian waters. This study took samples of coral mucus in 2010 at 3 (three) different locations, namely Bunaken (May); Morotai (September) and Raja Ampat (November), which focused on the analysis of Research on hard coral (Scleractinian coral) contaminated with bacteria is still not much done, especially in Indonesian waters. This study took samples of coral mucus in 2010 at 3 (three) different locations, namely Bunaken (May); Morotai (September) and Raja Ampat (November), which focused on the analysis of gram-positive and gram-negative bacteria. The method used for field sampling is time swim, which is by diving at a depth of 5-10 meters for \pm 30 minutes and randomly taking samples of coral mucus using siring or by taking directly on corals (reef branching). Mucus samples were analyzed by bacterial isolation in the laboratory. The result shows that there were differences between gram-positive and gram-negative bacteria in the three research sites and that gram-positive bacteria were higher or dominant. Further research that can identify the bacteria species and explain its relationship to the ecosystem is highly recommended.
\end{abstract}

Keywords: Bacteria, Scleractinian coral, gram-positive and -negative, Bunaken, Morotai, Raja Ampat

\begin{abstract}
Abstrak
Penelitian tentang karang keras (Scleractinian coral) yang terkontaminasi bakteri masih belum banyak dilakukan, terutama di perairan Indonesia. Penelitian ini mengambil sampel mucus karang pada tahun 2010 di 3 (tiga) lokasi berbeda, yakni Bunaken (Mei); Morotai (September) dan Raja Ampat (November), yang difokuskan pada analisis bakteri gram postif dan gram negatif. Metode yang digunakan untuk pengambilan sampel di lapangan adalah time swim, yaitu dengan penyelaman pada kedalaman 5-10 meter selama \pm 30 menit dan mengambil sampel mucus karang secara acak menggunakan siring atau dengan mengambil langsung pada karang (fraksi cabang). Sampel mucus dianalisis dengan cara isolasi bakteri di laboratorium. Hasil analisis menunjukkan bahwa ada perbedaan antara bakteri gram positif dan gram negative di tiga lokasi survei dan bakteri gram positif lebih tinggi atau dominan. Penelitian lebih lanjut yang dapat menentukan jenis bakteri serta menjelaskan hubungannya dengan ekosistem sangat disarankan untuk dilakukan.
\end{abstract}

Kata Kunci : Bakteri, Scleractinian coral, gram positif dan negatif, Bunaken, Morotai, Raja Ampat 


\section{PENDAHULUAN}

Indonesia memiliki wilayah pesisir terpanjang kedua setelah Kanada dan memiliki 17.504 pulau yang sebagian besar merupakan pulau-pulau kecil (Nontji, 1987). Hal ini menjadikan Indonesia sebagai salah satu negara maritim terbesar di dunia dan memiliki potensi sumberdaya alam perikanan dan kelautan yang sangat tinggi. Kawasan pesisir dan laut Indonesia memiliki potensi dan keanekaragaman hayati tertinggi di dunia (mega biodiversity) dan termasuk dalam kawasan CTC (Coral Triangle Center).

Salah satu kekayaan keanekaragaman hayati yang ada di Indonesia adalah ekosistem terumbu karang. Terumbu karang merupakan salah satu bagian dari ekosistem pesisir yang mempunyai manfaat sangat banyak. Manfaat itu antara lain sebagai tempat untuk memijah, mencari makan dan berlindung bagi ikan karang, terumbu karang juga dapat menghasilkan value tersendiri yaitu keindahannya bisa mendatangkan nilai ekonomi (Dahuri, 2003).

Meningkatnya kejadian pemutihan karang dan penyakit karang menunjukkan semakin tingginya ancaman terhadap ekosistem terumbu karang berikut keanekaragaman biota yang berasosiasi didalamnya. Fenomena pemutihan dan penyakit pada karang diduga akibat semakin tingginya tekanan ekosistem baik yang ditimbulkan dari aktivitas umat $m$ anusia dan pergerakkan perubahan iklim global. Bourne dkk., (2009) menyebutkan bahwa kejadian ini dapat mengganggu integritas "coral holobiont" yaitu komplek simbiosis antara hewan karang, algae endobiotik dan beranekaragam mikroorganisme.

Mikroorganisme memiliki peranan penting pada kesehatan dan penyakit hewan karang. Penyakit pada hewan karang dapat disebabkan oleh mikroorganisme pathogen, tekanan lingkungan, dan melemahnya hewan karang akibat kehilangan system imunitas inangnya. Komunitas bakteri yang berasosiasi dengan hewan karang telah banyak diketahui memiliki diversitas dan kelimpahan yang tinggi. Dinamika komunitas bakteri mengeksploitasi sejumlah ruang pada hewan karang termasuk mucus yang dihasilkan di permukaan karang, ruang atau relung intraselluler di dalam jaringan hewan karang, ruang di pada rangka hewan karang dan air laut sekita hewan karang (Raina dkk., 2009).

Bakteri dapat dikelompokkan menjadi dua, yaitu bakteri gram positif dan gram negatif yang didasarkan dari reaksi atau sifat bakteri terhadap cat tersebut. Hal ini dikembangkan oleh Hans Christian Gram, 1853-1938. Pengujian ini berguna untuk mengklasifikasikan kedua tipe bakteri ini berdasarkan perbedaan struktur dinding sel mereka. Bakteri gram negatif mempunyai struktur dinding sel berlapis tiga dengan ketebalan yang tipis berkisar antara 10$15 \mathrm{~nm}$. Komposisi dinding sel bakteri gram negatif ini terdiri dari lipid dan peptidoglikan. Konsentrasi lipid pada dinding sel bakteri gram negatif berkisar antara 11-22 \%. Bakteri gram negatif umumnya kurang rentan terhadap penisilin, kurang resisten terhadap gangguan fisik, dan persyaratan nutriennya relatif sederhana (Pelczar dan Chan 2005).

Bakteri gram positif mempunyai struktur dinding sel yang tebal antara $15-80 \mathrm{~nm}$ dan berlapis tunggal. Komposisi dinding sel terdiri dari lipid, peptidoglikan, dan asam tekoat. Konsentrasi lipid pada dinding sel bakteri gram positif berkisar antara 1-4 $\%$. Bakteri gram positif lebih rentan terhadap penisilin, dan persyaratan nutriennya relatif rumit pada banyak spesies (Pelczar dan Chan 2005). 
Penelitian ini bertujuan untuk : 1) Mengetahui komposisi rata-rata bakteri gram positif dan gram negative; serta 2) Menentukan bakteri yang paling dominan dari semua lokasi penelitian.
METODE PENELITIAN Lokasi Penelitian

Pengambilan sampel dilakukan pada 18-19 Mei 2010 di Taman Nasionali Bunaken, Sulawesi Utara $\left(\mathrm{N} 1^{\circ} \mathrm{E} 124^{\circ}\right)$; pada 24-25 September 2010 di Kabupaten Morotai, Halmahera Utara (S 02 ${ }^{\circ} \mathrm{E} 128$ ); dan di Kabupaten Raja Ampat, Papua Barat (S $00^{\circ}$ E $130^{\circ}$ ) pada 7-11 November 2010.

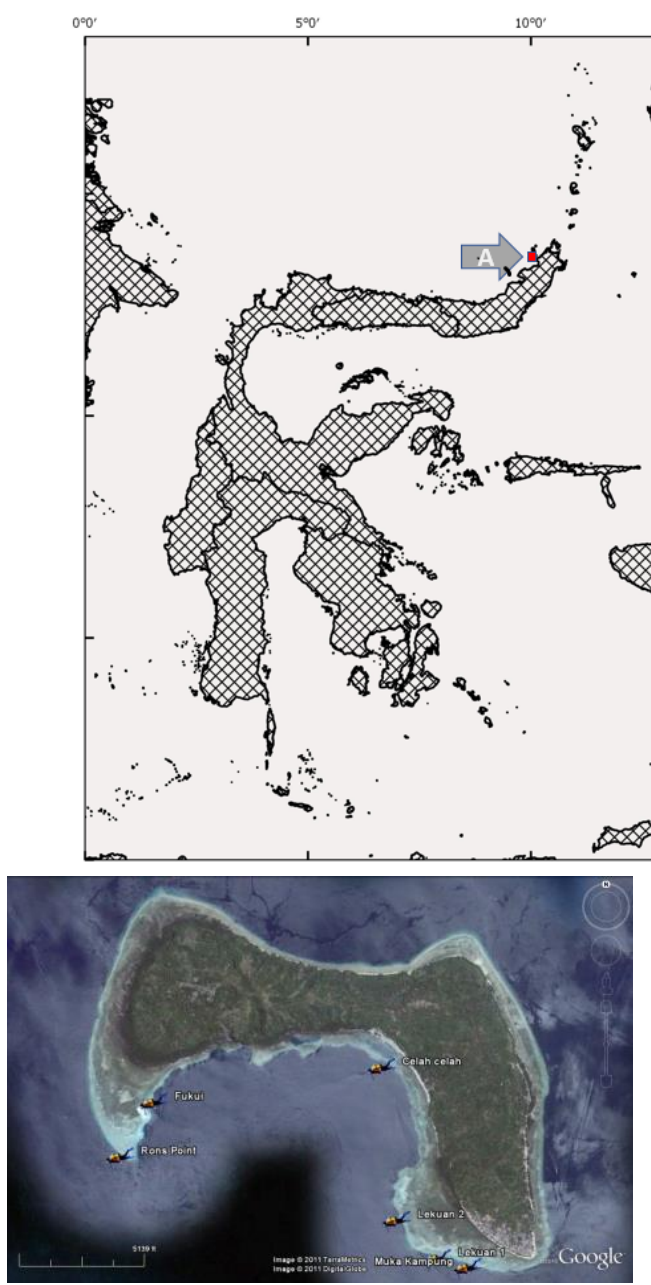

(A)

Gambar 1. Peta lokasi pengambilan data

Keterangan:

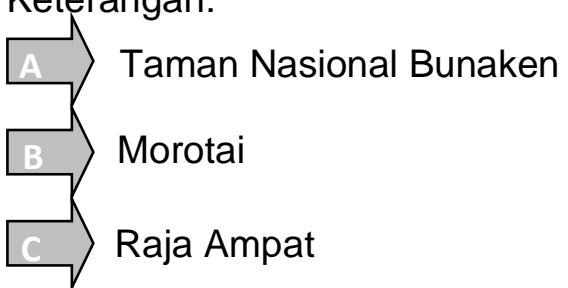

Sumber: Peta Rupa Bumi Indonesia 2016 terbitan BIG \& google map
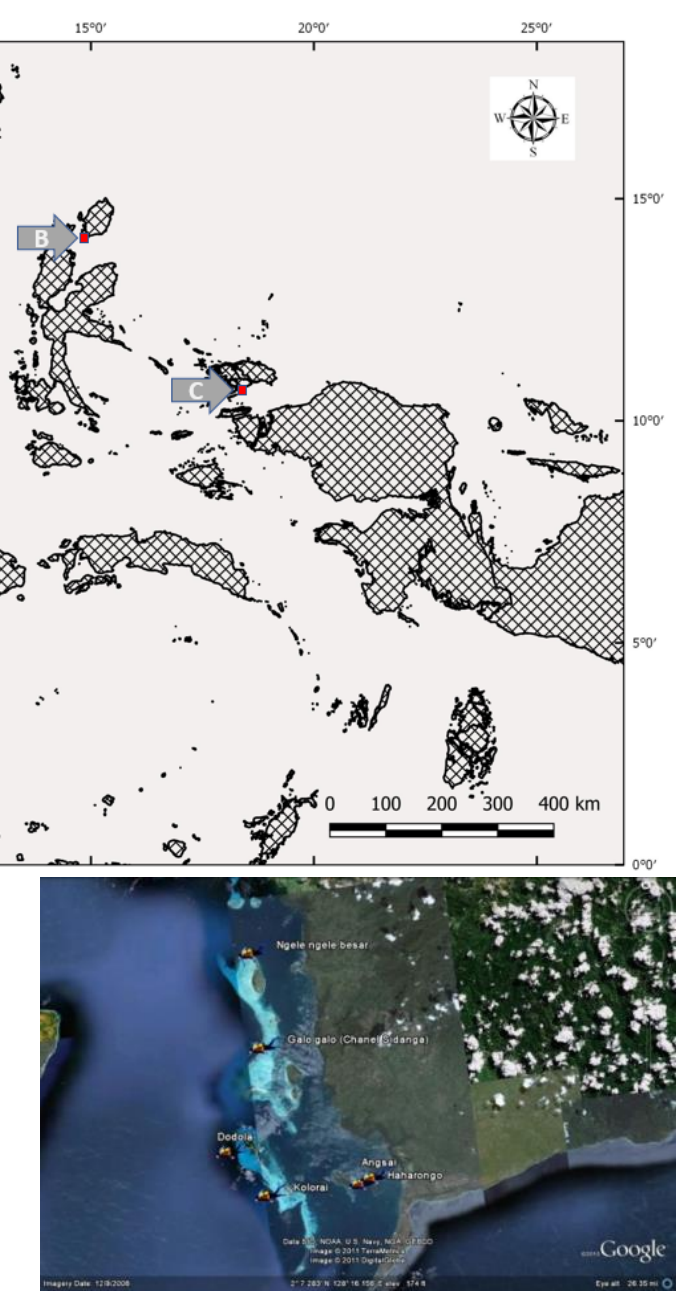

(B)

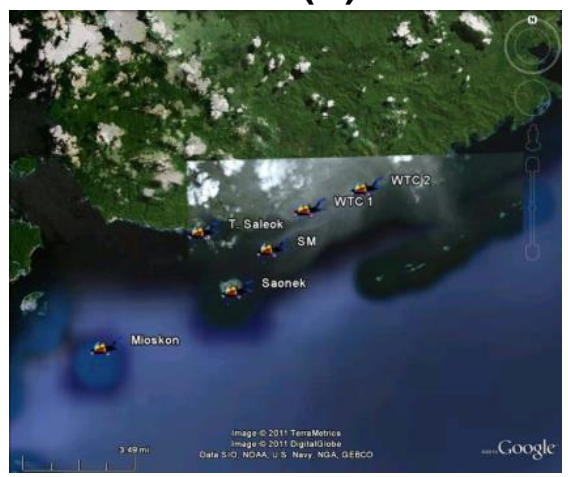

(C) 


\section{Pengambilan dan Analisis Data Sampel Bakteri Pada Karang}

Pengambilan sampel mucus dilakukan secara acak pada kedalaman 5-10m dengan menggunakan peralatan SCUBA diving dengan metode time swim (English dkk 1997). Untuk menganalisa bakteri gram + dan gram -

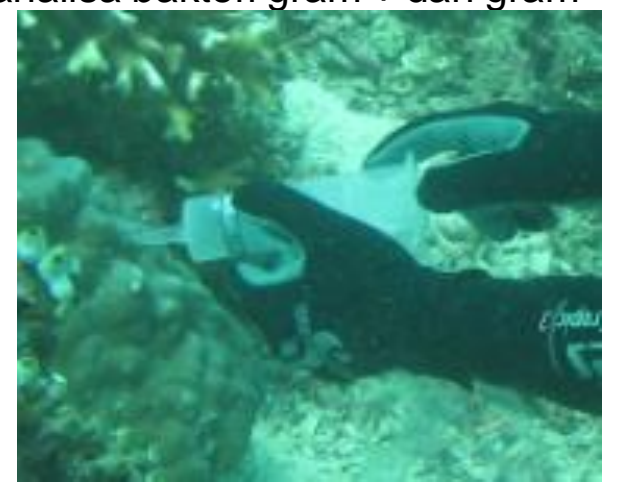

Gambar 2. Pengambilan mucus pada karang dengan menggunakan siring

Metode yang digunakan untuk isolasi bakteri dari karang yang mengalami bleaching adalah metode gores, tuang dan tanam menggunakan media agar

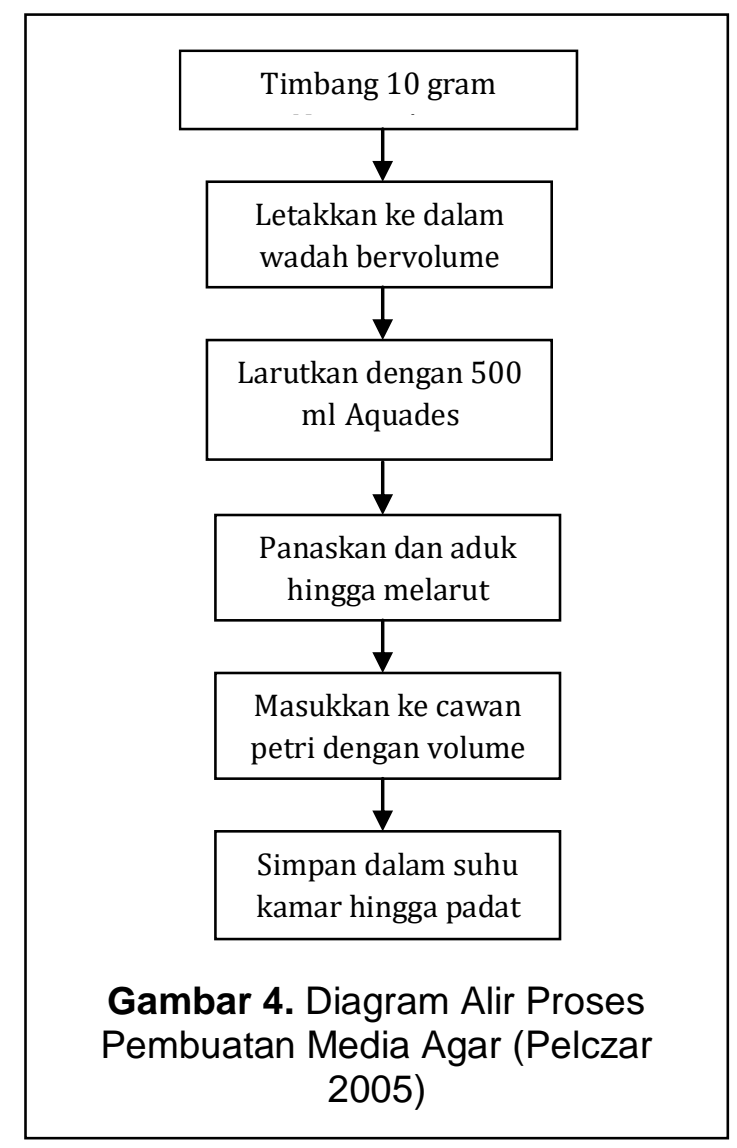

pada karang keras yang diindikasi mengalami penyakit (coral disease). Mucus karang diambil dengan menggunakan siring (Gambar 2.) dan disimpan dalam ziper bag yang kemudian sampel mukus tesebut dibawa ke laboratorium untuk dianalisis (Gambar 3).

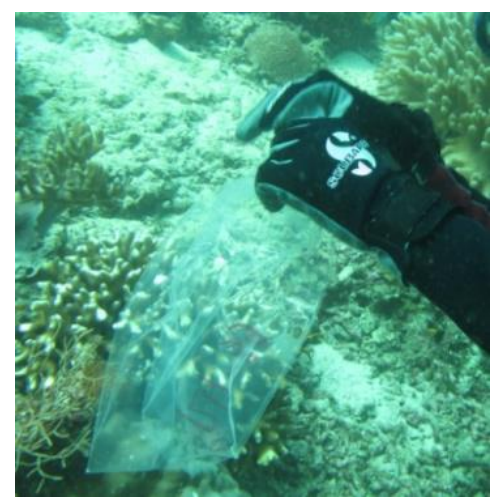

Gambar 3. Mucus disimpan di ziper bag untuk analisa di Laboratorium

dengan urutan kerja sebagai berikut: pembuatan media agar (Gambar 4) serta (2) isolasi dan Penyegaran Bakteri (Gambar 5).

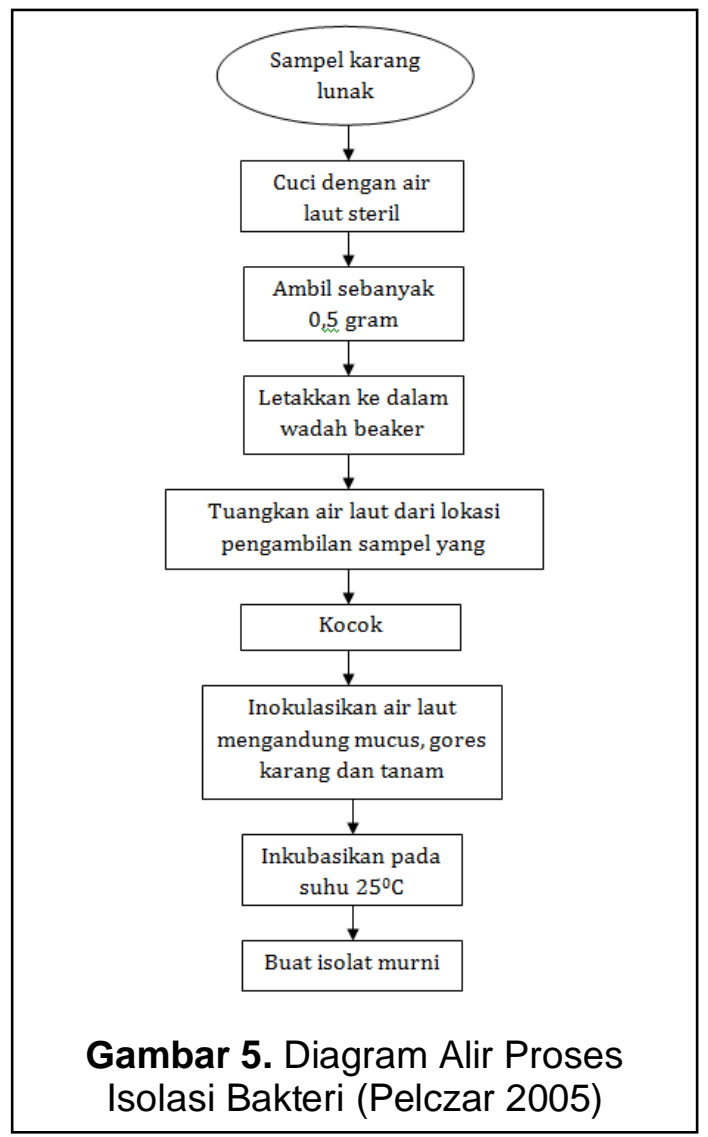




\section{Kualitas air}

Pengukuran kualitas air dilakukan guna mengetahui kondisi perairan Bunaken, Morotai dan Raja Ampat pada saat pengambilan data sampel bakteri pada karang. (Gambar 1). Parameter yang diukur langsung (in-situ) meliputi : suhu, salinitas, dan $\mathrm{pH}$. Sedangkan parameter: Oksigen terlarut (Dissolved Oxygen), Klorofil, Nitrat, Fosfat dan Amonia di analisis di Laboratorium Kualitas Perairan, Balai Riset dan Observasi Laut yang telah mengimplementasikan Sistem Manajemen Mutu Laboratorium
ISO/IEC 17025:2005 dari Komite Akreditas Nasional.

\section{HASIL DAN PEMBAHASAN}

Isolasi mikroorganisme dari hewan karang dan mucus karang dilakukan seluruhnya di Laboratorium Riset Kelautan (LRK), Laboratorium Kualitas Perairan, Balai Penelitian dan Observasi Laut (Sekarang Balai Riset dan Observasi Laut). Hasil identifikasi dengan metode pewarnaan gram dari mikroorganisme yang berhasil diisolasi dapat dilihat selengkapnya pada Gambar 6.

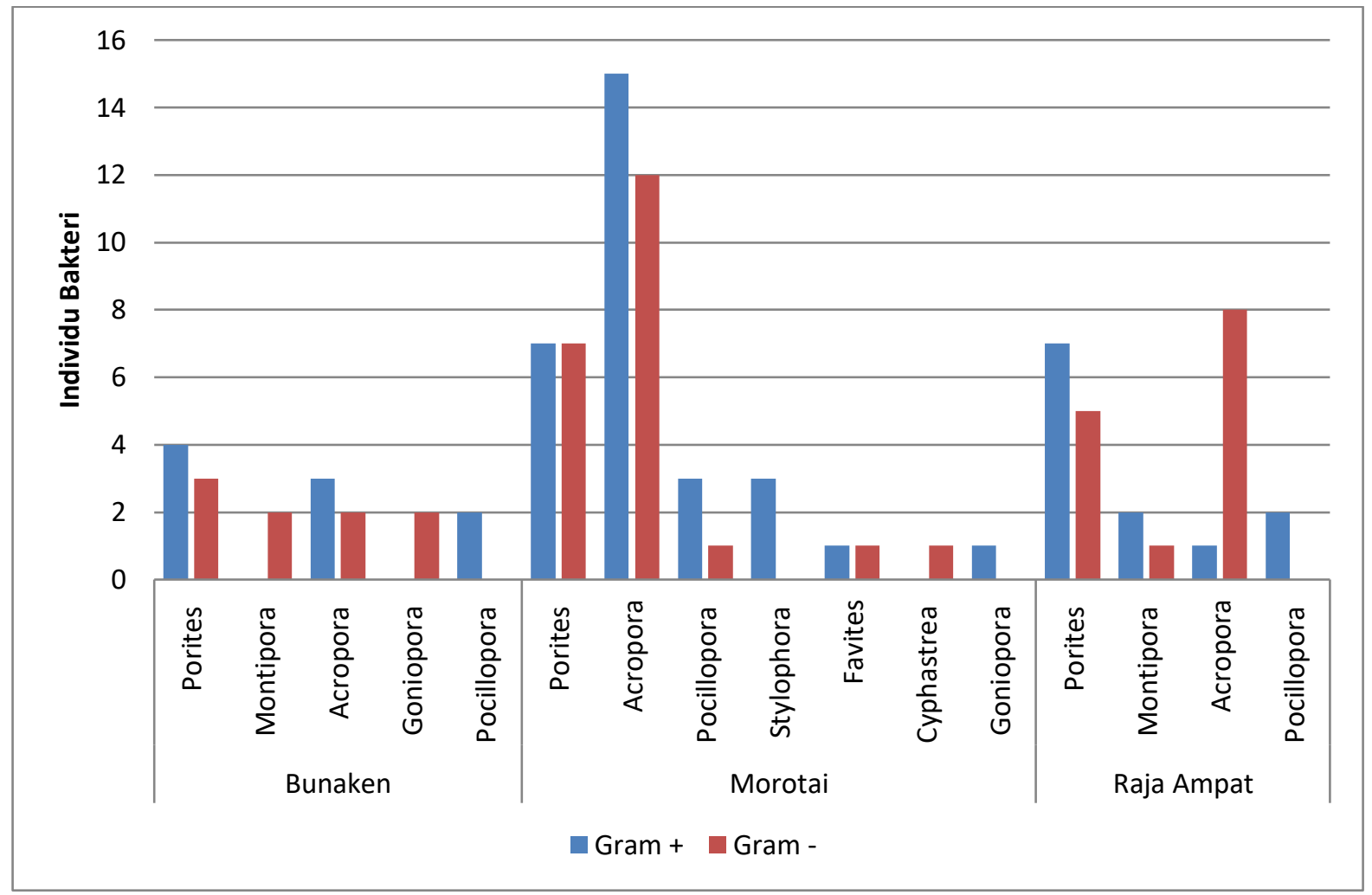

Gambar 6. Hasil Bakteri Gram positif dan negatif

\section{Bakteri Pada Karang di Taman Nasional Bunaken}

Hasil isolasi bakteri dan identifikasi awal dengan teknik pewarnaan gram dari 16 sampel karang dan mukus karang yang diperoleh dari 5 titik pengambilan sampel pada lokasi penelitian (TN Bunaken) menunjukkan bahwa bakteri isolat yang didapat dan tidak terkontaminasi termasuk ke dalam kelompok bakteri gram positif (8 isolat) dan bakteri gram negatif ( 9 isolat), juga terlihat bahwa dari jenis karang yang 
sama namun mendapat perlakuan dengan 3 cara pengisolasian yang berbeda menunjukkan kelompok bakteri yang berbeda seperti yang terlihat pada Porites nigrescens dari lokasi Rons Point. Isolat bakteri dari karang jenis Porites nigrescens termasuk dalam kelompok bakteri gram positif untuk bakteri yang di isolasi dengan metoda gores langsung dari air media hidupnya, sedangkan untuk metoda gores dari karang dan potongan karang yang di tanam pada media agarnya diketahui termasuk ke dalam kelompok bakteri gram negatif.

Hasil yang sama juga dijumpai pada jenis Pocillopora verrucosa dari lokasi pengambilan sampel di Celah Celah (Ampou dkk., 2015). Hasil penelitian Efrony dkk., (2007) terhadap karang jenis Pocillopora damicornis dan Favia favus menemukan adanya indikasi infeksi oleh bakteri jenis Vibrio coralliilyticus dan Thalosomonas loyaeana yang menyebabkan terjadinya bleaching dan lissis jaringan serta penyakit the white plague. Jenis Goniopora tenuidens dari lokasi Lekuan 1 dan Montipora danae dari lokasi pengambilan di Celah Celah menunjukkan kelompok bakteri gram negatif untuk isolat yang dilakukan dengan melakukan goresan dari air media hidupnya. Kelompok isolat bakteri gram positif ditemukan pada lokasi pengambilan sampel karang dan mukus karang yaitu Rons Point, Celah Celah, Lekuan 1, Lekuan 2, Muka Kampung dan Fukui.

Hasil pengukuran kualitas perairan di lokasi pengambilan data menunjukan hasil yang bervariasi di masing-masing parameter (Tabel 1). Parameter yang diukur meliputi parameter fisik (suhu dan TSS), biologi (klorofil), dan kimia (pH, DO, dan nutrien) di 6 stasiun, dengan 2 kedalaman (0 meter dan 5 meter). Nutrien yang dianalisis adalah nitrat, fosfat, dan ammonia (Lap.Penelitian, BROL, 2010).

Tabel 1. Hasil pengukuran kualitas air di lokasi pengambilan data di Taman Nasional Bunaken

\begin{tabular}{|c|c|c|c|c|c|c|c|c|c|c|}
\hline \multirow[b]{2}{*}{ Stasiun } & \multirow{2}{*}{$\begin{array}{l}\text { Kedalaman } \\
(\mathrm{m})\end{array}$} & \multicolumn{9}{|c|}{ Parameter } \\
\hline & & $\mathrm{pH}$ & $\begin{array}{c}\text { Suhu } \\
\left({ }^{\circ} \mathrm{C}\right)\end{array}$ & $\begin{array}{c}\text { Salinitas } \\
(\% 0)\end{array}$ & $\begin{array}{l}\text { TSS } \\
\text { (mg/l) }\end{array}$ & $\begin{array}{c}\mathrm{DO} \\
(\mathrm{mg} / \mathrm{l})\end{array}$ & Klorofil & $\begin{array}{l}\text { Nitrat } \\
(\mathrm{mg} / \mathrm{l})\end{array}$ & $\begin{array}{c}\text { Fosfat } \\
\text { (mg/l) }\end{array}$ & $\begin{array}{c}\text { Amonia } \\
(\mathrm{mg} / \mathrm{l})\end{array}$ \\
\hline \multirow{2}{*}{ St. 1} & 5 & 7.51 & 29 & 34 & 68 & 9.93 & 0.3077 & 0.143 & 0.0033 & 0.167 \\
\hline & 10 & 7.48 & - & 34 & 67 & 5.67 & 0.0861 & 0.088 & 0.0033 & 0.3294 \\
\hline \multirow{2}{*}{ St. 2} & 5 & 7.83 & 30 & 33 & 44 & 7.8 & 0.1023 & 0.136 & 0.005 & 0.2704 \\
\hline & 10 & 7.6 & - & 33 & 48 & 8.5 & 0.1023 & 0.047 & 0.0084 & 0.2999 \\
\hline \multirow{2}{*}{ St. 3} & 5 & 7.27 & 31 & 33 & 40 & 6.38 & 0.3069 & 0.059 & 0.005 & 0.108 \\
\hline & 10 & 7.24 & - & 32 & 92 & 7.09 & 0.3231 & 0.076 & 0.0017 & 0.108 \\
\hline \multirow{2}{*}{ St. 4} & 5 & 6.72 & 31 & 34 & 73 & 6.38 & 0.2208 & 0.056 & 0.0084 & 0.2704 \\
\hline & 10 & 7.04 & - & 34 & 64 & 7.09 & 0.1023 & 0.008 & 0.0084 & 0.2408 \\
\hline \multirow{2}{*}{ St. 5} & 5 & 7.08 & 29 & 35 & 50 & 11.34 & 0.3239 & 0.009 & 0.01 & 0.2408 \\
\hline & 10 & 7.08 & - & 34 & 84 & 7.79 & 0.4408 & 0.009 & 0.0017 & 0.2408 \\
\hline \multirow{2}{*}{ St. 6} & 5 & 7.21 & 30 & 34 & 63 & 10.64 & 0.3393 & $<0.001$ & 0.0502 & 0.2704 \\
\hline & 10 & 7.4 & - & 36 & 51 & 10.64 & 0.1023 & $<0.001$ & 0.0033 & 0.1818 \\
\hline \multicolumn{2}{|c|}{ Rata-rata } & 7.29 & 30 & 33.83 & 62 & 8.27 & 0.23 & 0.06 & 0.01 & 0.23 \\
\hline \multicolumn{2}{|c|}{ Baku Mutu* } & $7-8.5$ & $28-30$ & $33-34$ & 20 & $>5$ & - & 0.008 & 0.015 & 0.3 \\
\hline
\end{tabular}

*Menurut Keputusan Menteri Lingkungan Hidup No. 51 Tahun 2004 tentang Baku Mutu Air Laut

Secara umum, kondisi perairan lokasi pengambilan data di Taman Nasional Bunaken masih berada di bawah baku mutu yang ditetapkan oleh Keputusan
Menteri Lingkungan Hidup Nomor 51 Tahun 2004 tentang baku mutu air laut. Namun terdapat parameter yang berada di atas baku mutu yang 
ditetapkan, yaitu TSS dan nitrat. Nilai padatan total terlarut (TSS) pada perairan berkisar antara $40-92 \mathrm{mg} / \mathrm{L}$ dengan rata-rata $62 \mathrm{mg} / \mathrm{L}$. Nilai baku mutu TSS yang ditetapkan untuk kehidupan biota laut pada terumbu karang adalah $20 \mathrm{mg} / \mathrm{L}$ dan diperbolehkan terjadi perubahan sampai dengan $<10 \%$ konsentrasi rata2 musiman. Tingginya konsentrasi TSS bisa disebabkan oleh adanya aktivitas penyelaman di titik pengambilan sampel. Kadar Nitrat $\left(\mathrm{NO}_{3}^{-}\right)$pada perairan berkisar antara $<0,001$ $0,1429 \mathrm{mg} / \mathrm{L}$. Baku mutu konsentrasi nitrat yang ditetapkan untuk kehidupan biota laut adalah 0,008 mg/L. Kadar nitrat yang tinggi bisa disebabkan oleh adanya oksidasi senyawa nitrit menjadi nitrat pada perairan (Lap.Penelitian, BROL, 2010).

\section{Bakteri Pada Karang di Morotai}

Dari 24 sampel karang dan mucus karang yang diperoleh dari 6 titik pengambilan sampel pada lokasi penelitian (Kepulauan Morotai) menunjukkan bahwa bakteri isolat yang didapat dan tidak terkontaminasi termasuk ke dalam kelompok bakteri gram positif (29 isolat) dan bakteri gram negatif (24 isolat) seperti yang terlihat pada. Terlihat bahwa dari jenis karang yang sama namun mendapat perlakuan dengan 3 cara pengisolasian yang berbeda menunjukkan kelompok bakteri yang berbeda seperti yang terlihat pada Acropora donei, Acropora teres, Acropora valencienns dan Acropora intermedia dari titik pengambilan di Ngele-ngele besar, Galo-galo dan Kolorai. Isolat bakteri dari karang jenis Acropora donei termasuk dalam kelompok bakteri gram positif untuk hasil isolasi dengan metoda menanam potongan karang yang mengalami bleaching dan air media karang pada media agarnya sedangkan untuk metoda gores dari karang diketahui termasuk ke dalam kelompok bakteri gram negatif.

Jenis Acropora valenciennesi menunjukkan hasil isolat termasuk kelompok bakteri gram positif untuk hasil isolasi dengan metoda gores langsung dari air media karang dan kelompokbakteri gram negatif untuk metoda tanam potongan karang dan gores langsung potongan karang pada media agar. Hasil yang sama juga dijumpai pada jenis Pocillopora verrucosa dari lokasi pengambilan sampel di Kolorai yang menujukkan kelompok bakteri gram positif yang diisolasi langsung dari mucus karang dengan gores dan kelompok bakteri gram negatif untuk metoda yang ditetesi mucus karang. Kelompok isolat bakteri gram negatif hasil isolasi dari lokasi penelitian di Kepulauan Morotai menunjukkan jumlah yang lebih sedikit dibanding kelompok isolat bakteri gram positif. Jenis Porites stephensoni dari lokasi Galo-Galo menunjukkan hasil isolasi kelompok bakteri gram negatif untuk seluruh isolat yang dilakukan dengan metoda yang berbeda. Menurut Pelczar dan Chan (2005) banyak spesies bakteri gram-negatif yang bersifat patogen, yang berarti mereka berbahaya bagi organisme inang.

Kondisi kualitas perairan di lokasi pengambilan data di Morotai dapat diketahui melalui hasil pengukuran parameter kualitas air yang tertera pada Tabel 2. Meskipun terdapat parameter yang nilai pengukurannya di atas baku mutu yang ditetapkan oleh Keputusan Menteri Lingkungan Hidup No. 51 Tahun 2004 tentang baku mutu air laut, namun kondisi tersebut masih dalam batas toleransi dan secara umum masih sangat baik untuk mendukung kehidupan biota (karang) (Lap.Penelitian, BROL, 2010). 
Tabel 2. Hasil pengukuran kualitas air di lokasi pengambilan data di perairan Morotai

\begin{tabular}{|c|c|c|c|c|c|c|c|c|c|}
\hline \multirow[b]{2}{*}{ Stasiun } & \multirow{2}{*}{$\begin{array}{c}\text { Kedalaman } \\
(\mathrm{m})\end{array}$} & \multicolumn{8}{|c|}{ Parameter } \\
\hline & & $\mathrm{pH}$ & $\begin{array}{c}\text { Suhu } \\
\left({ }^{\circ} \mathrm{C}\right)\end{array}$ & $\begin{array}{c}\text { Salinitas } \\
(\% 0)\end{array}$ & $\begin{array}{l}\text { TSS } \\
\text { (mg/l) }\end{array}$ & Klorofil & $\begin{array}{l}\text { Nitrat } \\
(\mathrm{mg} / \mathrm{l})\end{array}$ & $\begin{array}{l}\text { Fosfat } \\
\text { (mg/l) }\end{array}$ & $\begin{array}{c}\text { Amonia } \\
(\mathrm{mg} / \mathrm{l})\end{array}$ \\
\hline \multirow{2}{*}{ St. 1} & 5 & 7.78 & 31 & 36 & 27 & 0.5107 & 0.0671 & $<0.001$ & 0.0364 \\
\hline & 10 & 7.75 & 30.3 & 38 & 33 & 0.7169 & 0.0745 & $<0.001$ & 0.0521 \\
\hline \multirow{2}{*}{ St. 2} & 5 & 8.32 & 32.2 & 33 & 29 & 10.937 & $<0.001$ & $<0.001$ & 0.0521 \\
\hline & 10 & 8.36 & 31.4 & 32 & 41 & 0.1015 & 0.0344 & $<0.001$ & $<0.01$ \\
\hline \multirow{2}{*}{ St. 3} & 5 & 8.23 & 31.1 & 31 & 40 & 0.5245 & 0.0059 & $<0.001$ & 0.0364 \\
\hline & 10 & 8.24 & 31 & 30 & 39 & 0.6268 & 0.0196 & $<0.001$ & $<0.01$ \\
\hline \multirow{2}{*}{ St. 4} & 5 & 7.77 & 31.2 & 37 & - & - & - & - & - \\
\hline & 10 & 7.89 & 31.7 & 37 & - & - & - & - & - \\
\hline \multirow{2}{*}{ St. 5} & 5 & 7.09 & 30.4 & 37 & 14 & 0.7623 & $<0.001$ & $<0.001$ & $<0.01$ \\
\hline & 10 & 7.12 & 30.4 & 36 & 16 & 0.3061 & 0.0049 & $<0.001$ & $<0.01$ \\
\hline \multirow{2}{*}{ St. 6} & 5 & 7.33 & 31.9 & 34 & 39 & 0.1868 & $<0.001$ & $<0.001$ & $<0.01$ \\
\hline & 10 & 7.28 & 31.9 & 34 & 18 & 0.1706 & 0.0017 & $<0.001$ & 0.0677 \\
\hline \multirow{2}{*}{ St. 7} & 5 & 7.5 & 32.1 & 34 & 27.5 & 0.3215 & $<0.001$ & $<0.001$ & $<0.01$ \\
\hline & 10 & 7.48 & 31.7 & 34 & 23.5 & 0.4068 & 0.0165 & $<0.001$ & $<0.01$ \\
\hline \multicolumn{2}{|c|}{ Rata-rata } & 7.72 & 31.31 & 34.50 & 28.92 & 1.30 & - & - & - \\
\hline \multicolumn{2}{|c|}{ Baku Mutu* } & $7-8.5$ & $28-30$ & $33-34$ & 20 & - & 0.008 & 0.015 & 0.3 \\
\hline
\end{tabular}

${ }^{*}$ Menurut Keputusan Menteri Lingkungan Hidup No. 51 Tahun 2004 tentang Baku Mutu Air Laut

Nilai suhu perairan pada saat pengukuran berkisar antara 30,3 $32,2^{\circ} \mathrm{C}$ dengan rata-rata $31,31^{\circ} \mathrm{C}$. Nilai baku mutu suhu air laut untuk biota laut terumbu karang berdasarkan Kepmen Lingkungan Hidup tahun 2004 adalah $28-30^{\circ} \mathrm{C}$ dan diperbolehkan terjadi perubahan sampai dengan $<2^{\circ} \mathrm{C}$ dari suhu alami. Meskipun melebihi baku mutu, namun suhu perairan pada saat itu masih dalam kisaran yang aman untuk mendukung kehidupan biota laut. Nilai salinitas juga menunjukan hal yang sama dengan suhu.

Meskipun nilai hasil pengukuran berkisar antara 30 - $38 \%$ dengan ratarata $34,50 \%$, namun diperbolehkan terjadi perubahan sampai dengan $<5 \%$ salinitas rata-rata musiman . Sehingga salinitas perairan masih memenuhi baku mutu yang dipersyaratkan. Parameter lainnya yang juga bernilai diatas baku mutu yg ditetapkan adalah konsentrasi TSS (28.92 mg/l). Nilai baku mutu TSS berdasarkan Kepmen
Lingkungan Hidup tahun 2004 untuk terumbu karang adalah $20 \mathrm{mg} / \mathrm{L}$ dan diperbolehkan terjadi perubahan sampai dengan $<10 \%$ konsentrasi rata2 musiman (Lap.Penelitian, BROL, 2010)

\section{Bakteri Pada Karang di Raja Ampat}

Hasil isolasi bakteri dan identifikasi awal dengan teknik pewarnaan gram dari 16 sampel karang dan mucus karang yang diperoleh dari 5 titik pengambilan sampel pada lokasi penelitian menunjukkan bahwa bakteri isolat yang didapat termasuk ke dalam kelompok bakteri gram positif (14 isolat) dan bakteri gram negatif (18 isolat). Jenis Acropora valenciennesi menunjukkan hasil isolat termasuk kelompok bakteri gram positif untuk hasil isolasi dengan metoda gores langsung dari air media karang dan metoda tanam potongan karang. Hasil yang sama juga dijumpai pada jenis Pocillopora verrucosa dari lokasi pengambilan sampel di Teluk Saonek.

Kelompok isolat bakteri gram positif ditemukan pada lokasi pengambilan 
sampel karang dan mucus karang yaitu Saonek, WTC 1, WTC 2, Tanjung Saleok, dan Mioskon seperti yang terlihat pada. Kelompok isolat bakteri gram negatif hasil isolasi dari karang dan mucus karang di Raja Ampat didapati pada seluruh lokasi yang dijadikan titik pengambilan sampel mucus karang. Karang dan mucus karang yang dijadikan sampel untuk diteliti mengenai kejadian pemutihan karang dan penyakit karang serta fenomena coral mucus merupakan karang yang telah mengalami kerusakan baik itu karena bleaching atau terserang suatu jenis penyakit tertentu, sehingga dapat diduga bahwa kedua jenis kelompok isolat bakteri yang didapat merupakan kelompok bakteri yang patogen. Dugaan tersebut didasarkan pada hasil penelitian Lopez dkk., (2002) yang menunjukkan bahwa mikroba yang diisolasi baik dari air laut dan dari permukaan karang yang mengalami penyakit Black Band Disease (BBD) itulah yang menginfeksi karang.

Kondisi kualitas perairan sangat berpengaruh terhadap

keberlangsungan hidup ekosistem terumbu karang. Berdasarkan hasil pengukuran parameter kualitas air di lokasi pengambilan data, perairan menunjukan kondisi yang masih baik untuk mendukung kehidupan biota laut (terumbu karang) (Tabel 3). Meskipun terdapat parameter yang nilainya di atas baku mutu yang ditetapkan (salinitas, nitrat, fosfat, dan ammonia), namun secara umum, kondisi perairan masih dalam batas yang aman untuk biota laut (Lap.Penelitian, BROL, 2010).

Tabel 3. Hasil pengukuran kualitas air di lokasi pengambilan data di perairan Raja Ampat

\begin{tabular}{|c|c|c|c|c|c|c|c|c|c|c|}
\hline \multirow[b]{2}{*}{ Stasiun } & \multirow[b]{2}{*}{$\begin{array}{c}\text { Kedalaman } \\
\text { (m) }\end{array}$} & \multicolumn{9}{|c|}{ Parameter } \\
\hline & & $\mathrm{pH}$ & $\begin{array}{c}\text { Suhu } \\
\left({ }^{\circ} \mathrm{C}\right)\end{array}$ & $\begin{array}{c}\text { Salinitas } \\
(\%)\end{array}$ & $\begin{array}{c}\text { TSS } \\
(\mathrm{mg} / \mathrm{l})\end{array}$ & $\begin{array}{c}\mathrm{DO} \\
(\mathrm{mg} / \mathrm{l})\end{array}$ & Klorofil & $\begin{array}{l}\text { Nitrat } \\
(\mathrm{mg} / \mathrm{l})\end{array}$ & $\begin{array}{l}\text { Fosfat } \\
(\mathrm{mg} / \mathrm{l})\end{array}$ & $\begin{array}{c}\text { Amonia } \\
(\mathrm{mg} / \mathrm{l})\end{array}$ \\
\hline \multirow{2}{*}{ TM } & 5 & 8.5 & 30 & 35 & 32 & 5.75 & 0.1007 & 0.0534 & 0.0074 & $<0.01$ \\
\hline & 10 & 8.3 & 30 & 35 & 9 & 5.17 & 0.2338 & 0.0551 & 0.0142 & 0.1842 \\
\hline \multirow{2}{*}{ WTC } & 5 & 8.5 & 30 & 34 & 4 & 5.24 & 0.2354 & 0.0357 & 0.0125 & $<0.01$ \\
\hline & 10 & 8.5 & 30 & 35 & 41 & 5.34 & 0.2362 & 0.0583 & 0.0243 & 0.0811 \\
\hline \multirow{2}{*}{ SM } & 5 & 8.5 & 30,5 & 35 & 20 & 5.75 & 0.1177 & 0.039 & 0.0091 & 0.1017 \\
\hline & 10 & 8.5 & - & 35 & 20 & 5.51 & 0.1177 & 0.0856 & 0.0142 & 0.7409 \\
\hline \multirow{2}{*}{ MS } & 5 & 8.5 & 29 & 36 & 10 & 5.48 & 0.3385 & 0.047 & 0.0193 & 0.0192 \\
\hline & 10 & 8.5 & 30 & 35 & 15 & 3.99 & 0.22 & 0.0631 & 0.0108 & 0.0811 \\
\hline \multirow{2}{*}{ SN } & 5 & 8.5 & 31 & 36 & 21 & 5.14 & 0.2362 & 0.0551 & 0.0074 & $<0.01$ \\
\hline & 10 & 8.5 & 29 & 35 & 3 & 4.57 & 0.1015 & 0.0502 & 0.0108 & $<0.01$ \\
\hline \multirow{2}{*}{ TS } & 5 & 8.5 & 30 & 35 & 2 & 5.14 & 0.3231 & 0.0583 & 0.026 & 0.1223 \\
\hline & 10 & 8.5 & 30 & 35 & 3 & 5.41 & 0.3223 & 0.0454 & 0.0108 & $<0.01$ \\
\hline \multicolumn{2}{|c|}{ Rata-rata } & 8.48 & 30 & 35.08 & 15 & 5.21 & 0.22 & 0.05 & 0.01 & 0.19 \\
\hline \multicolumn{2}{|c|}{ Baku Mutu* } & $7-8.5$ & $28-30$ & $33-34$ & 20 & $>5$ & - & 0.008 & 0.015 & 0.3 \\
\hline
\end{tabular}

${ }^{*}$ Menurut Keputusan Menteri Lingkungan Hidup No. 51 Tahun 2004 tentang Baku Mutu Air Laut 


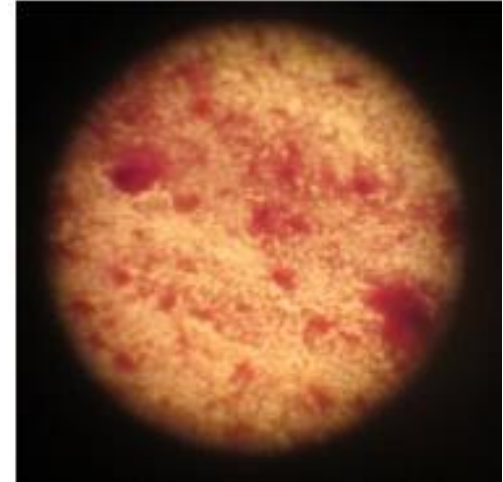

A

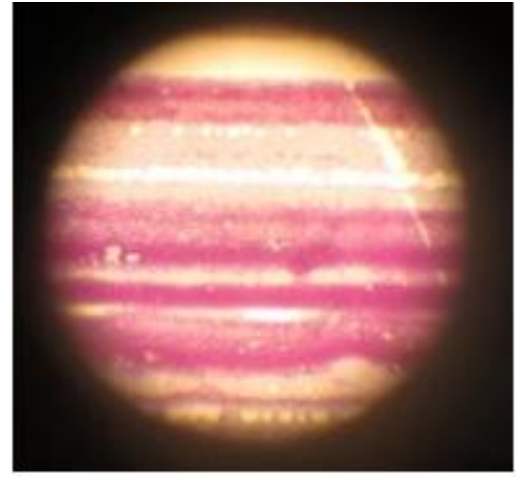

B

Gambar 7. Struktur gram positif $=A(+)$ dan gram negatif $=B(-)$ dilihat dari mikroskop $=5,5$ Micronmetric (mm). (Sumber: Ampou dkk, 2015)

Hasil analisis statistik menggunakan ttest menunjukan bahwa terdapat perbedaan antara bakteri gram-positif karang di tiga lokasi pengambilan data, dimana gram positif yang lebih dan gram-negatif yang terdapat pada dominan. (Tabel 4).

Tabel 4. Hasil uji t-test terhadap perbedaan bakteri gram-positif dan gram-negatif di Bunaken, Morotai, dan Raja Ampat

\begin{tabular}{lrr}
\hline & Gram + & Gram - \\
\hline Mean & 3.1875 & 2.8125 \\
Variance & 14.5625 & 12.02917 \\
Observations & 16 & 16 \\
Pearson Correlation & 0.768459 & \\
Hypothesized Mean Difference & 0 \\
df & 15 \\
t Stat & 0.6 \\
P $(T<=t)$ one-tail & 0.278731 \\
t Critical one-tail & 1.75305 \\
$\mathrm{P}(T<=t)$ two-tail & 0.557462 \\
$\mathrm{t}$ Critical two-tail & 2.13145 \\
\hline
\end{tabular}

\section{KESIMPULAN DAN SARAN}

\section{Kesimpulan}

1. Jenis genus karang rata-rata yang mengandung gram positif dan negatif adalah Acropora $s p$ dan Porites sp.

2. Berdasarkan analisa Statistika tTest didapatkan hasil bahwa ada perbedaan antara bakteri gram+ dan gram - di tiga lokasi survey dimana gram + lebih tinggi.

3. Kualitas perairan di ketiga lokasi menunjukan kondisi yang masih dalam kondisi normal dan baik untuk mendukung kehidupan biota laut terumbu karang

\section{Saran}

Perlu adanya penelitian lebih lanjut sampai pada tahapan uji jenis bakteri serta perlu dilakukan monitoring secara periodik baik pada lokasi yang sama atau lokasi lain agar bisa menambah referensi khususnya bakteri pada karang. 


\section{Ucapan Terima kasih}

Penulis mengucapkan terima kasih kepada Balai Penelitian dan Observasi Laut (sekarang Balai Riset dan Observasi Laut) atas dukungannya lewat dana DIPA-TA. 2010. Conservation International Indonesia di Waisai Raja Ampat, DKP Raja Ampat, Nasijaha Diving Club-Ternate, DKP Kabupaten Morotai, DKP Provinsi Sulut, Balai Taman Nasional, Bunaken dan semua pihak yang mendukung sehingga penelitian ini bisa berjalan dengan baik.

\section{Daftar Pustaka}

Ampou, E.E., I. Triyulianti, and S.C. Nugroho. 2015. Bakteri Asosiasi Pada Karang Scleractinia Kaitannya Dengan Fenomena LaNina Di Pulau Bunaken. Jurnal Kelautan Nasional, Kementerian Kelautan Dan Perikanan 10 No. 2 (August): 55-63.

Anonimous. 2007. Siaran Pers : Enam Negara Sepakati Kerjasama Kelola dan Konservasi Segitiga Karang. No 90.PDSI/XII/2007.

Banin, E., Ben-Haim, Y., Israely, T., Loya, Y., and Rosenberg, E. 2000. Effect of The Environment on The Bacterial Bleaching of Corals. Water, Air and Soil Pollution, (123) : 337 - 352.

Bengen, D.G, 1998. Sinopsis Analisis Statistic

Multivariabel/Multidimensi.

Program Pascasarjana.IPB. Bogor

Benson, A.A., and Muscatine, L. 1974. Wax In Corals Mucus : Energy Transfer From Corals to Reef Fishes. Limnology and Oceanography, (5) : 19.

Bourne, D.G., Garren, M., Work, T.M., Rosenberg, E., Smith, G.W., and Harvell, C.D. 2010. Microbial
Disease and The Coral Holobiont. Trends in Microbiology, (12) : 554 $-562$.

Buddemeier, RW and Wilkinson, CR. (1994) Global Cimate Change and Coral Reefs: Implications for people and reefs. IUCN: Gland (Switzerland), $107 \mathrm{pp}$.

Dahuri, R. 2003. Keanekaragaman Hayati Laut aset pembangunan berkelanjutan Indonesia. PT Gramedia. Pustaka Utama, Jakarta.

Dobretsov, S and Yuan Qian, P. 2004. The role of epibotic bacteria from the surface of the soft coral Dendronephthya sp. in the inhibition of larval settlement. Jornal of Experimental Marine Biology and Ecology, (299) : 35 50.

English, S., C. Wilkinson, and V. Baker. 1997. Survey Manual for Tropical Marine Resources. 2nd edition., ASEAN. Townsville, Australia: Australia Marine Science Project, Living Coastal Resources, Australian Institute of Marine Science.

Efrony, R., Loya, L., Bacharach, E., and Rosenberg. $2007 . \quad$ Phage Therapy of Coral Disease. Coral Reefs, (26) : 7 - 13 .

Hoegh-Guldberg, O. (1999) Climate Change, pemutihan karang and the future of the world's coral reefs. Greenpeace: Sydney (Australia), 28 pp.

Keputusan Mentri Lingkungan Hidup No.51. 2004. Baku Mutu Air Laut untuk Wisata Bahari.

Koren, O. and Rosenberg, E. 2006. Bacteria Associated with Mucus and Tissues of the Coral Oculina patagonica in Summer and Winter. Journal of Applied and Environmental Microbiology, (72) : 5254 - 5259.

Legendre, L and P. Legendre, 1983. Numerical ecology. Elsevier 
Scientific Publishing Company. $419 \mathrm{p}$.

Lopez, J.G., Zerkle, A.L., Bonheyo, G.T., and Fouke, B.W. 2002. Partitioning of Bacterial Communities between Seawater and Healthy, Black Band Diseased, and Dead Coral Surfaces. Applied and Environmental Microbiology, (68) : $2214-2228$.

Laporan Penelitian. 2010. Studi Operasional Oseanografi Untuk Konservasi Ekosistem Terumbu Karang. Balai Penelitian dan Observasi Laut, Kementerian Kelautan dan Perikanan tahun.

Nontji, A. 1987. Laut Nusantara.

Penerbit Djambatan. Jakara. 114 p.

Nybakken, J. W. 1992. Biologi Laut: Suatu Pendekatan Ekologis. Diterjemahkan oleh H. M. Eidman, Koesobiono, D. G. Bengen, M. Hutomo, dan S. Sukardjo. PT Gramedia. Jakarta. xv + $459 \mathrm{~h}$

Nybakken, J.W. 1988. Biologi Laut: Suatu Pendekatan Ekologis. Alih Bahasa:H.M. Eidman, Koesoebiono, D.G. Bengen, M. Hutomo, dan S. Sukardjo.Penerbit PT. Gramedia. Jakarta.

Raymundo, L.J., Couch, C.S., Bruckner, A.W., Harvell, C.D., Work, T.M., Weil, E., Woodley, C.M., Dahlgren, E.J., Willis, B.L., Sato, Y., and Aeby, G.S. 2008. Coral Diseases Handbook: Guidelines for Assessment, Monitoring \& Management. Currie Communications. Australia.

Rosenberg, E., Kushmaro, A., Winters, E. K., Banin, E., and Yoss, L. 2009. The Role of Microorganisms in Pemutihan karang. The Journal of International Society for Microbial Ecology, (9) : 1751 - 1762.

Nakajima, R., Yoshida, E.T., Azman, E.B.A.R., Zaleha, K., Othman,
E.B.H.R and Tod, E.T. 2009. In situ release of coral mucus by Acropora and its influence on the heterotrophic bacteria. Aquatic Ecology, (43) : 815 - 823.

Nurhayati, T., Suhartono , MT., Nuraida L., dan Poerwanto, SB. 2006. Karakterisasi Awal Inhibitor Protease dari Bakteri yang Berasosiasi dengan Spons Asal Pulau Panggang, Kepulauan Seribu. Hayati (13) : $58-64$.

Pelczar MJ and Chan ECS. 2005. Dasar-Dasar Mikrobiologi 2. Jakarta: UI-Press

Raina, JE., Tapiolas D., Willis BL dan Bournei DG. 2009. Coral Associated Bacteria and Their Role in the Biogeochemical Cycling of Sulfur. Applied and Environmental Microbiology, (75) : $3492-3501$.

Sukarno. M., M. Hutomo., M. K. Moosa dan P. Darsono. 1983. Terumbu Karang di Indonesia: Sumberdaya, Permasalahan dan Penegelolaannya. Proyek Sudi Potensi Sumberdaya Alam Indonesia. Studi Potensi Sumberdaya Ikan. LONLIPI. Jakarta.

Suharsono. 1996. Jenis-Jenis Karang yang Umum Dijumpai Di Perairan Indonesia. P3O-LIPI Jakarta. 116 $\mathrm{h}$

Setyobudiandi, I., Sulistiono., Yulianda, F., Kusmana, C., Hariyadi,S., Damar,A., Sembiring, A., Bahtiar. 2009. Sampling dan Analisis Data Perikanan dan Kelautan, Terapan Metode Pengambilan Contoh di wilayah Pesisir dan Laut. Fakultas Perikanan dan IImu Kelautan Institut Pertanian Bogor, Bogor. Vi +313 Hal.

Tomascik, T., A. J. Mah, A. Nontji, dan M. K. Moosa. 1997. The Ecology of The Indonesian Seas. Periplus Edition. Singapore. 
Wild, C., Huettel, M., Klueter, A., Stephen, G. K., Rasheed, M.Y.M., and Jørgensen, B.B. 2004. Coral Mucus Function as An Energy
Carrier and Particle Trap in The Reef Ecosystems, Nature (428) : $66-70$. 